\title{
THE EFFECTS OF COMPANY SIZE, COMPANY RISK AND AUDITOR'S REPUTATION ON TENURE: AN ARTIFICIAL ROTATION TESTING
}

\author{
Junaidi \\ Faculty of Informatics Technology and Business, \\ Universitas Teknologi Yogyakarta, Indonesia \\ (masjoen@uty.ac.id) \\ Novia Nurul Khasanah \\ Faculty of Informatics Technology and Business, \\ Universitas Teknologi Yogyakarta, Indonesia \\ (hasna.novia@yahoo.com) \\ Nurdiono \\ Faculty of Economics and Business, \\ Universitas Lampung, Indonesia \\ (nurdiono_pb@yahoo.com)
}

\begin{abstract}
This study aims to empirically examine the effects of firms' size, firms' risk, and auditors' reputations on tenure in an artificial rotation. The phenomenon of artificial auditor (audit firm) rotations in Indonesia is an interesting topic, deserving further study. Artificial auditor rotations indicate a condition in which, conceptually, there has been a change of auditor that makes the relationship between the auditor and the client end, but in effect, the relationship is still going on. Regulations for mandatory auditor rotations causes audit firms or their partners to cheat the system by changing the name of their firm, or partners, to allow them to continue auditing the same client. This research samples 110 companies listed on the Indonesian Stock Exchange between 2000 and 2010, which were obtained using a purposive sampling method. The results of a statistical test indicate that a company's size significantly influences the tenure. The variables of firms' risk and auditors' reputations do not have significant effects on tenure, statistically. This research is expected to contribute both theoretically and practically, especially to the regulations on auditors' rotations. Auditing quality is an important factor that must be maintained by the auditor profession, to maintain the independence of auditors. In the auditing practices in Indonesia, regulators should consider the artificial rotation phenomenon that occurs in Indonesia, so the practice of auditing can run better.
\end{abstract}

Keywords: tenure, rotation, size, reputation, quality, risk.

\section{INTRODUCTION}

There are pros and cons about the research that challenges whether or not rules for mandatory auditor rotations are necessary. Those who do not agree with the mandatory rotation of auditors consider that the longer the tenure is, the more competent the auditors become, since they understand their client's conditions better, so that they can perform their auditing work properly (Geiger \& Raghunandan, 2002; Myers et al., 2003; Carcello \& Nagy, 2004; Ghosh \& Moon, 2005). Conversely, those supporting the mandatory rotation of auditors consider that the longer the tenure is, the greater is the possibility of diminishing the independence of the audit, due to the excessive familiarity between the auditor and their client (Mautz \& Sharaf, 1961; Jackson et al., 2008; Carey \& Simnett, 2006; Junaidi \& Hartono, 2010; Junaidi et al., 2012). The tenure shows the length of the relationship between the auditor and client.

Regulations on auditors' tenure in Indonesia have changed several times, namely from the Ministry of Finance Decree No. 423/KMK.06/ 
2002, KMK No. 359/KMK.06/2003, PMK No. 17 of 2008 to the published Law No. 5 of 2011, and Government Regulation No. 20 of 2015 on Public Accounting Practices. This suggests that the regulator is watching the auditing profession, in order to maintain the professionalism of the auditors. This research was motivated by the phenomenon of the artificial rotation of auditors in Indonesia, prior to Government Regulation No. 20 of 2015 on Public Accounting Practices being issued. There has not been much research done in Indonesia that reveals the phenomenon of the artificial rotation of auditors. The artificial rotation of an auditor is a condition in which, conceptually, there has been a change of auditor, ending the relationship between the auditor and the client, but in fact the relationship is still ongoing (Junaidi et al., 2012, 2014; Junaidi, 2014). It means the regulation on mandatory auditor rotation does not end the relationship between auditor and client; the phenomenon of artificial rotation ensures that the tenure between the auditor and the client continues.

This study aims to empirically examine the effect of firms' size, risks, and auditors' reputations on tenure. In practice, the regulations on tenure have not been empirically proven to be effective, because of the phenomenon of artificial rotation. Therefore, it is very important to uncover what causes the length of tenure, because according to DeAngelo (1981); Mansi et al. (2004); Mai et al. (2008) and Junaidi et al. (2012), a long tenure can reduce an audit's quality (independence).

The quality of the audits conducted by public accountants can be judged from the size of the audit firm conducting the auditing processes (DeAngelo, 1981b). The large audit firms supply higher quality audits because they possess a comparative advantage in monitoring individual auditor behavior. Big-four auditors are regarded as being more qualified to conduct the auditing process than the non-big-four auditors. This is because the big-four auditors have more clients and resources than the smaller ones, so they do not have to depend on a particular client. In addition, since the big-four auditors are considered to have good reputations by the public, it is believed that they will conduct their audits more carefully. However, the accounting scandals such as Enron, that involved the audit firm of Arthur Andersen made the public question the quality of the audits conducted by auditors, especially the big-four auditors. Therefore, the important matter relating to tenure is independence. Independence can be reduced due to the emotional relationship between the auditor and the client in a long tenure (Nasser et al., 2006).

From the clients' perspectives, the complexity of financial statements will make them appoint auditors with good reputations. While from the auditors' perspective, large companies have highly complex accounts, so there is the potential for the audit firm to make large sums of money. This will certainly encourage the auditors to maintain links and relationships with their big clients. Also from the clients' perspective, the company's risk can affect the quality of the auditing. Company risk is often associated with the company's financial condition. The financial condition demonstrates the soundness of the company in real terms. In companies that are experiencing financial difficulties, many going concern indicator problems can be found (Ramadhany, 2004). Companies that are experiencing financial difficulties are willing to be audited by the same auditor, since the auditor has a greater understanding of the company's condition. In addition, each industry has its own separate and different accounting issues, so that the auditing needs of each industry are also different. Industrial specialization can be developed by an auditor, by increasing their expertise in a particular industry, or by choosing a market that is focused on a particular type of industry (Craswell et al., 1995).

The results of this study are expected to contribute both in theory and in practice. In theory the results of this study may support the concept of independence, that ethically an auditor should continue to maintain his/her professionalism. The auditor's interest in the income received from their clients should not undermine their independence. For the regulators, the results of this study support that 
tenure should remain regulated. It appears that, to date, tenure continues to be governed by the Government of Indonesia through Government Regulation No. 20 of 2015 on Public Accounting Practices.

\section{THEORY AND HYPOTHESIS}

\section{Independence}

Independence means that an auditor must not easily be influenced, and is impartial. Auditors are obliged to be honest, not only with the management and owners of the company they audit, but also with the creditors and other parties that trust them to do their duty as public accountants (Christiawan, 2002). Auditors should have an independent attitude both in reality and in performance. Independence in reality exists when a public accountant manages to maintain an unbiased manner during an audit, while independence in their performance is the result of other people's perceptions of the independence of public accountants (Maria \& Pinnarwan, 2003).

Auditing Standards Section 220 states that in all matters relating to the engagement, an independent mental attitude must be maintained by the auditor. Those standards require auditors to be independent, and not easily influenced, because they carry out work in the public's interest. People's trust in auditors' independence is very important for the development of the public accounting profession.

\section{Auditing Quality}

Auditing quality is defined as the possibility that the auditor will detect and report material misstatements (DeAngelo, 1981b). The reporting process conducted by an auditor depends on the auditor's ability to disclose such breaches. An auditor can produce good quality audited statements if the auditor does his/her duties professionally (Nurchasanah \& Rahmawati, 2003). The term 'auditing quality' has different meanings depending on the viewpoint of the recipient or the provider of the audit service. Users of financial statements state that good quality auditing occurs when the auditor can give assurances that there are no material misstatements in the financial statement. While the auditors' views are that high quality auditing occurs when the auditors work in accordance with the existing professional standards, are able to assess the audited businesses' risks with the aim of minimizing the risk of litigation, and to avoid to the ruin of the auditors' reputations. Therefore, auditing quality is an important thing for an auditor during the auditing process.

To be able to perform their obligations, there are three components that must be possessed by auditors, namely competence, independence and due professional care. In carrying out their functions, an auditor often experiences conflicts of interest with the company management. The management might want the company's operating results, or its performance, to appear to be more successful by depicting them using better data, with the intention of getting an award (e.g. bonus). To achieve these objectives, the company's management often compels the auditor to produce audited financial statements in accordance with their wishes. An auditor has a strategic position for both the management and the financial statement's users. Besides, the users of financial statements put a lot of faith in the work of auditors. This faith in the audited financial statements, by their users and in the service that is provided by the auditors, requires that the auditors pay attention to the quality of the auditing they conduct.

To carry out their professional duties, the auditors should be guided by the code of ethics for accountants, and the professional and accounting standards applicable in Indonesia. Auditors must consider their integrity and objectivity when carrying out their duties, by acting honestly and decisively, without pretension, so that they can act fairly and not be influenced by certain parties to fulfill those parties' personal interests (Khomsiyah \& Indriantoro, 1998).

Deis and Giroux (1992) conducted a study of four aspects that are considered to have a relationship with an audit's quality, namely: (1) Tenure, implying that the longer an auditor works for the same client, the lower the quality 
of his/her audits become, (2) number of clients, hinting at the idea that the greater the number of clients an auditor has, the better the auditing quality will be, since an auditor with a large number of clients will try to maintain his/her good reputation, (3) the financial health of the client, meaning that the healthier the financial condition of the client is, the bigger the tendency will be to press the auditor to not follow the standard procedures and (4) a review by a third party, implying that the quality of the audit will increase if the auditor knows that his/her service is going to be reviewed by someone else.

\section{The Firms' Size}

The size of a company can be measured by the total assets of the company. Big companies require very complex audits. Therefore, the potential revenue to be received by an auditor during these audits is also great. Dhaliwal et al. (2008) examined the relationship between nonaudit fees, audit fees and auditing quality. They found that audit fees have a significant effect on the quality of the auditing. Hartadi (2009) found evidence that income significantly affects the quality of auditing. Francis and $\mathrm{Yu}$ (2009) argue that a firm's size will significantly affect the quality of its auditing, which in this case is associated with the amount of potential revenue to be made by the public accounting firms. The larger the company's size is, measured by its total assets, the greater are the potential revenues to be earned from this company, so that auditors are willing to audit the company for a long period. If the auditor no longer audits the company, the auditor will lose a significant part of his/her income, which would affect the total revenue received. Suparlan and Andayani (2010), in their study mentioned that firms' size negatively affects the change of the auditor, the smaller the company the less expensive the fee of the auditor is, but the bigger the desire is to change the auditor. From the above description the author formulates the following research hypothesis.

H01: Firms' size has no effect on tenure.

\section{The Firms’ Risk}

The previous studies' results suggest that company risk influences the change of the auditor, but they were not all conclusive. Sinason et al. (2001); Setyorini and Ardiati (2006); Prastiwi and Wilsya (2009) stated that a company's financial problems do not affect changing the auditor. While a company that is experiencing financial difficulties tends to change its auditor more frequently than a healthy company [Schwartz \& Menon, 1985; Nasser et al., 2005; Hudaib \& Cooke, 2005].

Company risk is seen from the company's financial condition. This financial condition is very likely to be a factor in the process of changing auditors. Francis and Wilson (1988) stated that companies with high debt ratios which are financially unhealthy tend to use auditors with high independence levels, to enhance their shareholders and creditors' confidence in the companies, to reduce any risk of litigation.

According to Chow and Rice (1982), the issue of a qualification report is a significant reason for a client to change their auditor. Schwartz and Menon (1985) found that the failure of the client creates a greater tendency for them to change their auditor. A company in financial difficulties has a greater incentive to change its auditor, rather than the company that stays healthy, as the managers of the healthy company attempt to project a good image of their company

However, auditor rotation is not always initiated by the client, but can be started by the auditor. Shu (2000) also found that the resignation of an auditor is positively associated with their client's legal exposure. Previous arguments show that, as a result of the client replacing the auditor, or the auditor resigning, the auditor will not issue a going concern auditing opinion for companies in a good financial condition (Ramadhany, 2004). Companies that are experiencing financial difficulties want to be audited by the same auditor, because that auditor has a better understanding of their financial conditions. 
The company's risk is measured by Altman's Z score 1968. Ramadhany (2004) stated that the financial condition variable, which is calculated by Altman's $Z$ score discriminant analysis, negatively affects the possibility of receiving a going concern opinion. This finding is supported by Santosa and Wedari (2007) who state that the better the financial condition of the company is, the less likely the auditor will be to give a going concern auditing opinion, because the auditor will only provide this opinion if the company is said to be insolvent or is struggling to continue in business.

Schwartz and Menon (1985); Nasser et al. (2006) found that companies that are experiencing financial problems will tend to change auditors, as compared to healthy companies. While Prastiwi and Wilsya (2009) stated that the company's financial problems did not affect the change of auditor. This study was supported by research conducted by Sinason et al. (2001); Setyorini and Ardiati (2006) which stated that the financial condition does not affect the change of auditor. Companies experiencing financial distress want to be audited by the same auditor, and keep them on longer tenures, because these auditors understand the financial conditions of the companies. From the above discussion, we propose the following research hypothesis.

H02: The firms' risk has no effect on tenure

\section{The Auditors' Reputation}

Auditors are classified into two different groups, namely auditors who are affiliated with the big four firms and auditors who are not affiliated with the big four. When an auditor claims to be an auditor of good standing, because he/she has connections to the big four, he/she will strive to maintain his/her good name and avoid actions that lower his/her standing (Fanny \& Saputra, 2005). After the Enron case, the international, world-wide audit companies shrank down to only four companies, known as the big four auditors. Big Four auditors affiliated with local firms in Indonesia include:
1. Auditing Firm of Purwantono, Sarwoko and Sandjaja affiliated with Ernest and Young (EY).

2. Auditing Firm of Osman Bing Satrio and Partners affiliated with Deloitte Touche Tohmatsu (Deloitte).

3. Auditing Firm of Siddharta and Widjaja affiliated with Klynveld Peat Marwick Goerdeler (KPMG).

4. Auditing Firm of Haryanto Sahari and Partners affiliated with Pricewaterhouse Coopers (PwC).

According to the rules of the Indonesian Institute of Certified Public Accountants, foreign auditors are allowed to perform service activities in Indonesia by affiliating with local auditors. For that, the measurement of the auditor's reputation is separated into two, namely auditors affiliated with the big four and those not affiliated with the big four. Auditors are responsible for providing high quality information that is useful for making decisions. Auditors of good standing will likely issue a going concern audit opinion, if their client's firm has problems related to it being a going concern (Junaidi \& Hartono, 2010). Going concern audit opinion is opinion issued by auditors to ascertain whether the company can maintain its existence.

An auditor's reputation reflects his/her achievements, and the trust that he/she is held in by the public. Fanny and Saputra (2005) state that the client usually perceives that accountants coming from the large firms of auditors, who have affiliations with international auditors, are of a higher quality because the auditors have characteristics that can be associated with quality, such as training, international recognition and experience, as well as their peer's respect. Auditors who have a good reputation and name can provide a better quality of audit, including exposing any going concern problems, in order to maintain their reputation. Choi et al. (2010) found a significant effect of the size of the public accounting firms on auditing's quality. Big four auditors provide a higher quality than the smaller or non-reputable auditors do. Small auditors are more likely to 
depend on a specific client, compared to the big auditors.

Ghosh and Moon (2005) showed that an audit's quality improves with the increase of tenure. Sinason et al. (2001) and Nasser (2006) found empirical evidence that the type of auditor significantly affects the auditor's length of employment and possibility of being replaced. These results are consistent with the stakeholders' image that the big four auditors provide a better service and performance than the nonbig four auditors. Therefore, companies that have cooperated with the big four have the possibility of extending their tenure, compared to companies that work with non-big four auditors. The determining of which auditors get into the big four is conducted based on the performance of the auditors concerned, and it has been proven empirically that the big four auditors give more satisfaction than the non-big four, so that the possibility of firms replacing their auditors becomes lower. From the above description, we propose the following research hypothesis.

H03: Auditors' reputation has no effect on tenure.

\section{Tenure and Auditors' Rotation Rules}

Auditor rotation regulations in Indonesia have experienced several changes. To maintain the auditors' quality, the Indonesian Government has issued the Decree of the Minister of Finance No. 423/KMK.06/2002, which was renewed by the Decree of the Minister of Finance No. $359 /$ KMK.06/2003. This regulation stated that the longest permissible time for the provision of public services for a client's financial statements, conducted by a audit firm, is five consecutive fiscal years and by a partner, the longest time is for three consecutive fiscal years. Further, the regulation is re-updated by the Minister of Finance Regulation No. 17, 2008. The second part of the regulation describes the time limitation of the provision of services by an auditor, in this case the services provision for the general auditing of a financial statement of an entity, is referred to by Article 2 Paragraph (1) letter a, which states that this can be conducted by auditors for no more than six consecutive fiscal years, and by a public accountant for no more than three consecutive fiscal years. On the $6^{\text {th }}$ of April 2015, the government issued Government Regulation No. 20 of 2015 on Public Accounting Practices which is a further re-arrangement of Act No. 5 of 2011 on Public Accountants. In connection with the public accounting firms' rotation rules set forth in Article 11 of the Regulation 20/2015, which in Article 11 paragraph (1) explains that: "The provision of auditing services on historical financial information referred to in Article 10 Paragraph (1) letter a, to an entity by a public accountant is limited to no more than five consecutive years."

The phenomenon of the artificial rotation of auditors in Indonesia would be an interesting problem to be investigated, considering whether the length of tenure is in order to improve the auditing quality or it is only because the auditor does not want to lose clients, and income. Tenure is a period of engagement between the auditor and client, related to the agreed provision of auditing services, or it can also be interpreted as a term for the relationship between an auditor and client. There are a number of studies linking quality with auditing assignment periods. According to DeAngelo (1981a), with the long time span and auditing assignment sustainability, the auditing services' users (such as shareholders, bondholders, managers, employees, government agencies and others) will benefit because they can save the costs associated with the evaluation of their audit's quality. Although DeAngelo (1981a) did not explicitly state that an audit's quality is correlated to a specific period of time as the optimum time for the assignment of an auditor, he did argue that various benefits will be lost if the auditor's assignment period is only for a short time period.

There is an argument supporting the existence of a negative relationship between the duration of an auditor's assignment and the quality of the audits. Mautz and Sharaf (1961) state that the auditors should be aware of various conditions that can affect their behavior, and 
may also reduce their independence. For example, the longer the relationship lasts between an auditor and client, this can have an adverse effect on the independence of the auditor, as his/her objectivity of the client will be reduced over time (Deis and Giroux, 1992).

\section{Types of Industries}

Each industry has different characteristics. The client's business operations and risks vary by their industry type (Lim et al., 2010). Research shows that the nature and incidence of errors in financial statements vary by industry (Maletta \& Wright, 1996). With a long tenure, an auditor has a better understanding of his/her clients and their industries, which implies that the auditor will develop a reputation for conducting better audits of his/her clients.

\section{The Research's Framework}

In this study, the dependent variable is tenure. The independent variables are the company's size, the company's risk and the auditor's reputation, while the type of industry is the control variable.

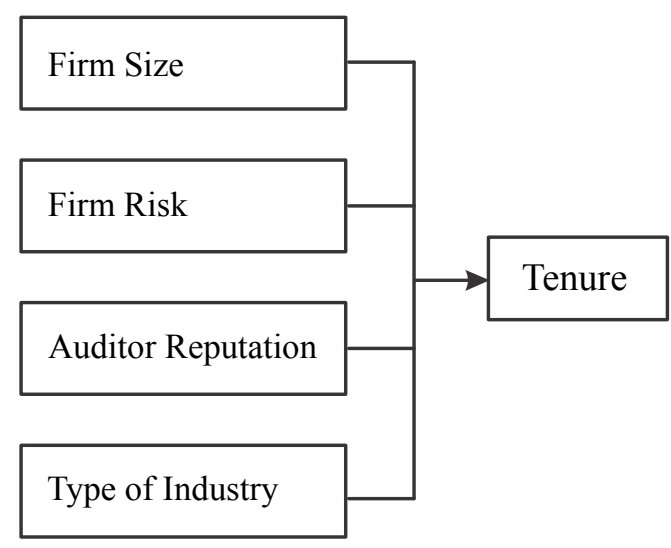

Figure 1. Research's Framework

\section{RESEARCH METHOD}

\section{Sample}

The sample used in this study is all the companies listed on the Indonesian Stock Exchange in the period 2000-2010. Allegedly, during that period, many artificial rotation phenomena occured, because the mandatory rotation of auditors was established in 2002, revised in 2003, and then again in 2008. The sampling method used was purposive sampling with the following criteria:

1. Companies listed on the Indonesian Stock Exchange, other than banks, in the period from 2000 to 2010.

2. Companies that published complete annual financial statements in the period from 2000 to 2010 .

3. Companies in which the artificial rotation of auditors has allegedly occurred.

\section{Reasearch Data}

The required data are as follows: Auditor's name, partner's name, the name of the auditor's affiliate and the audited financial statements from 2000 to 2010 , to determine the tenure. In addition, data about the balance sheets, income statements and cash flow statements of companies that have been audited from 2000 to 2010 are required.

\section{The Operational Definition of the Variable}

\section{The Firms' Size}

The firms' size variable was measured by using the client's natural log of total assets. The total size of the assets is used because the larger the total assets owned are, the bigger the potential revenue and non-attestation services provided to the auditors will be. Big potential revenues would encourage auditors not to lose the client, so that the tenure continues.

\section{The Firms’ Risk}

Company risk variables are assessed using Altman's Z score. This study is using Altman (1968) so that banking companies are excluded from the sample. Once the value of the $Z$ score is known, then the ordinal data of Altman's Z score formula are made, as follows:

$$
\begin{aligned}
Z= & 0.717 X_{1}+0.847 X_{2}+ \\
& 3.107 X_{3}+0.420 X_{4}+0.998 X_{5}
\end{aligned}
$$

Notation:

$$
\begin{aligned}
& \mathrm{X} 1=\text { working capital/total assets } \\
& \mathrm{X} 2=\text { retained earnings/total assets }
\end{aligned}
$$


$\mathrm{X} 3=\mathrm{EBIT} /$ total debt

$\mathrm{X} 4=$ market value of equity/total assets

$\mathrm{X} 5=$ Sales/total assets

If the $\mathrm{Z}$ value is above 2.9 , the company is classified as a non-distress company, and is rated 3. If the $\mathrm{Z}$ value is between 1.2 and 2.9 , the company's condition is included in the grey area, and is rated 2. While if the $\mathrm{Z}$ value is below 1.2, the company is classified as a distress company and is rated 1 .

\section{Auditors' Reputation}

The auditor's reputation is measured by using dummy variables. An auditor's reputation is classified into two groups, namely the auditor affiliated with the big four auditor firms (value of 1) and the auditor affiliated with a non-big four firm (value of 0 ).

\section{Tenure}

Tenure indicates the period of assignment to audit a firm's books, which implies the length of the relationship between the auditor and client. Tenure is measured by the number of years during the period of observation.

\section{Type of Industry}

Type of Industry shows the characteristics of each industry type. According to the Indonesian Stock Exchange, industries can be divided into nine categories, namely:

1. Agriculture

2. Mining

3. Basic Industries and Chemicals

4. Miscellaneous Industries

5. Customer Goods Industry

6. Property, Real Estate and Building Construction

7. Infrastructure, Utilities and Transportation

8. Finance

9. Trade, Services and Investment

\section{Test of Statistics}

Descriptive Statistics and Classic Assumption Testing

Descriptive statistics provide a description of data that can be seen from the mean value, standard deviation, maximum and minimum. Classic assumption testing includes multicollinearity, autocorrelation, and heteroscedasticity.

\section{Hypotheses Testing}

The regression model used in this research is:

$$
\begin{aligned}
\text { TENURE }= & \alpha+\beta \text { 1SIZE }+\beta \text { 2RISK }+ \\
& \beta \text { 3REP }+\beta \text { 4INDUSTRY }+\varepsilon
\end{aligned}
$$

Notation:

TENURE = length of auditor-client relationships that is measured by the number of years

SIZE = company's size using the logarithm of the total assets of the client's company.

RISK $=$ company's risk is measured using Altman's Z score.

REP $=$ auditor's reputation is calculated using the dummy variables. If the company is audited by an auditor who is affiliated with the big four firms it will be given 1, and non-big four will be given 0 .

INDUSTRY $=$ a control variable that indicates the type of the client's industry

$\alpha=$ constant.

$\beta 1, \beta 2, \beta 3, \beta 4=$ regression coefficients. $\varepsilon=$ error.

Hypotheses testing used multiple linear regression analysis with a significance level $(\alpha)$ of 0.05 . If the $\mathrm{p}$-value is less than $0.05, \mathrm{H} 0$ will be rejected.

\section{THE RESEARCH ANALYSIS}

\section{Data Description}

Based on the sampling criteria, the sample data in Table 1 are obtained, as follows. 
Table 1. Sample Data

\begin{tabular}{lc}
\hline \multicolumn{1}{c}{ Description } & Amount \\
\hline Companies registered in 2000-2010 & 293 \\
Financial industry (banking) & $(25)$ \\
Other than financial industry (banking) & 268 \\
Incomplete financial statements & $(77)$ \\
Audited company and allegedly artificial rotation did not occur & $(81)$ \\
Audited company and allegedly artificial rotation occurred & $\mathbf{1 1 0}$ \\
\hline
\end{tabular}

The samples distribution, based on the auditorclient relationship, is shown in Table 2. From Table 2 it is seen that 14 companies were audited by the same auditor for six consecutive years, 22 companies for seven consecutive years, 23 companies for eight consecutive years, 29 companies for nine consecutive years, 8 companies for over ten consecutive years, while 14 companies were audited for 11 consecutive years.

Table 2. Tenure Distribution

\begin{tabular}{ccc}
\hline Tenure & Amount & \multicolumn{1}{c}{ Percentage } \\
\hline 6 consecutive years & 14 & 12.73 percent \\
7 consecutive years & 22 & 20.00 percent \\
8 consecutive years & 23 & 20.91 percent \\
9 consecutive years & 29 & 26.36 percent \\
10 consecutive years & 8 & 7.27 percent \\
11 consecutive years & 14 & 12.73 percent \\
\hline
\end{tabular}

An auditor's reputation is categorized as an auditor who is affiliated either with a big four firm or not. The majority of companies sampled in this study are companies audited by auditors who are affiliated with the big four firms, amounting to 75.25 percent of the total sample.

Table 3. Auditors' Distribution

\begin{tabular}{lc}
\hline \multicolumn{1}{c}{ Auditor } & Percentage \\
\hline Affiliated with big four & 75.25 percent \\
Not affiliated with big four & 24.75 percent \\
\hline & 100 percent \\
\hline
\end{tabular}

\section{Descriptive Statistics}

This study focuses on tenure as the dependent variable, and the size of the company, the risk to the company and the auditor's reputation as the independent variables, while the type of industry served as the control variable. The following is a statistical description of each variable.

Table 4. Descriptive Statistics

\begin{tabular}{lccl}
\hline \multicolumn{1}{c}{ Variable } & Minimum & Maximum & Mean \\
\hline LSIZE & 10 & 18 & 13.78 \\
RISK & 1 & 3 & 2.15 \\
REP & 0 & 1 & \\
TENURE & 1 & 11 & 4.79 \\
INDUSTRY & 0 & 1 & \\
\hline
\end{tabular}

Table 4 shows that the minimum size value is 10 , the maximum value is 18 and the mean is 13.78. The minimum value of company's risk is 1 , the maximum value is 3 , and the mean is 2.15 . While the minimum value for tenure is 1 , the maximum value is 11 and the mean is 4.79 .

\section{Classic Assumption Testing Results}

Classic assumption testing results show that the model has fulfilled all the classical assumptions of multicollinearity, autocorrelation and heteroscedasticity, as required by the multiple linear regression method ${ }^{1}$.

\section{Hypotheses Testing Results}

The regression results (Table 5) show an adjusted value $\mathrm{R}^{2}$ of 0.024 , and a significant model with a $p$-value of 0.00 . This means that only 2.4 percent of tenure, as the dependent variable, is explained by firms' size, firms' risk, auditors' reputation, or industry variables, while

\footnotetext{
${ }^{1}$ Statistical testing for classical assumptions indicating VIF values less than 10 means that multicolinearity does not occur. Further tests further indicate that the value of Durbin Waston (DW) is 1.09 so there is no autocorrelation, and Glejser test results show that none of the independent variables are statistically significant, so heteroscedastisity does not occur.
} 
the rest (97.6 percent) is explained by other factors outside the model. Furthermore, it is shown that the model with a dependent variable of tenure, and independent variables of size, risk, auditors' reputation and industry variables is considered proper, with a significance level from ANOVA models of 0.00 . The results of the regression testing appear in Table 5.

Table 5. Regression Testing

\begin{tabular}{lcc}
\hline \multicolumn{1}{c}{ Variables } & $\mathrm{B}$ & P-Value \\
\hline CONSTANT & 1.237 & 0.141 \\
LSIZE & 0.277 & 0.000 \\
RISK & -0.147 & 0.195 \\
REP & 0.027 & 0.902 \\
INDUSTRY & 0.009 & 0.821 \\
\hline
\end{tabular}

The size variable has a positive coefficient of 0.277 and a significance value of 0.000 , which is below 0.05 . Because the significance level is smaller than $\alpha=0.05, \mathrm{H} 01$ is rejected. This study statistically demonstrates empirical evidence that the size of a company has a significant effect on tenure. These results suggest that the bigger companies, that are proxied by total assets, push for longer relationships with their auditors. The larger the size of the company is, the greater is the potential revenue provided by the client to the auditor. Therefore the auditor does not want to lose this potential revenue, and also seeks a long tenure. This is in line with research conducted by Suparlan and Andayani (2010) where the size of the company is associated with its changes of auditor. The research result states that big companies very rarely make their auditor's change, most clients change auditor after being audited by the same auditor for five consecutive years. Therefore, it is very possible that the auditor also wants a long relationship with the client. The implication is that, because of the great revenue potential from large companies, the auditor may not maintain his/her independence.

The firms' risk variable has negative coefficients and is insignificant. Because the significance value is 0.195 (above 0.05), then H02 cannot be rejected. Therefore firms' risk does not affect the tenure. From the research sample it is seen that 23.33 percent of the companies are listed as being non-distress companies, while 38.50 percent of companies are classed as being in the grey areas, and 38.17 percent of companies are considered to be in distress. This means that companies experiencing financial distress will continue to replace their auditors. This is most likely because the auditors failed to detect significant weaknesses in the company's internal controls. The results are consistent with the research conducted by Schwartz and Menon (1985); Nasser et al. (2006) who found that companies experiencing financial problems would tend to change auditors more frequently, compared to healthy companies. So companies with financial problems do not want a long relationship with their auditors.

The reputation variable has a negative coefficient and is insignificant ( $p$-value $=0.902$ ). Since the significance value is above $0.05, \mathrm{H} 03$ cannot be rejected. Therefore, it can be said that an auditor's reputation does not affect their tenure. The samples distribution shows that 75.25 percent of the sampled companies were audited by an auditor who was affiliated with the big four firms. Although statistically it is insignificant that an auditor's reputation affects their tenure, the sample companies used more auditing services provided by auditors from firms affiliated with the big four. This is in accordance with the image that the stakeholders have. It shows that an auditor who is connected with the big four firms provides a better quality audit than a non-big four auditor. The control variable showed that the type of industry shows an insignificant result on tenure. However, conceptually clients will certainly choose auditors who are in accordance with the desired specifications of the clients. This will imply that auditors can develop their expertise in accordance with the needs of their clients' industries.

\section{CONCLUSION}

The issuing of government regulations on limitations for auditors' service provisions to clients encourages the phenomenon of artificial 
rotation. As a rule, if the client has rotated the auditor, but the auditor-client relationship is still established, as indicated by the length of tenure, this breaks the issued regulations Therefore, it is important to empirically reveal several factors that affect tenure. Statistical testing results show that the size of a company significantly affects the tenure. Companies' risks statistically do not have a significant effect on tenure. Furthermore, an auditor's reputation is also shown not to have a significant affect on tenure. The findings imply that auditor (partner) relationships need to be regulated, to maintain the audit quality as set out in the Public Accountants Professional Standards. These findings support Government Regulation No. 20 of 2015 regarding Public Accounting Practices.

\section{Limitations and Suggestions}

In this study, there are some limitations due to the incomplete data that the companies have, so that the sample in this research is rather limited. This study only used as its sample public companies that performed an artificial rotation, whereas there are many non-public companies which also do this, and need to be investigated. This study only uses three independent variables: The company's size, the company's risk and the auditor's reputation, and one control variable, the type of industry. Further research can add study variables, such as culture, to reveal whether the length of tenure is also influenced by cultural elements. In addition, it is also important to reveal empirically why a limit of five years tenure was chosen.

\section{REFERENCES}

Altman, Edward I 1968. 'Financial ratios, discriminant analysis and prediction of corporate bankruptcy'. Journal of Finance, 4, 589-609.

Carcello, Joseph V., and Albert L. Nagy, 2004. 'Audit firm tenure and fraudulent financial reporting'. Auditing: A Journal of Practice \& Theory,23 (2), 55-69.

Carey, Peter, and Roger Simnett, 2006. 'Audit partner tenure and audit quality'. The Accounting Review,81 (3), 653-676.
Chow, C. W., and S. J. Rice, 1982. 'Qualified audit opinions and auditor switching'. The Accounting Review,57 (April), 326-335.

Choi, Jong-Hag., Chansog (Francis)Kim, JeongBon Kim and Yoonseok Zang, 2010. 'Audit office size, audit quality and audit pricing'. Auditing: A Journal of Practice \&Theory, 29 (1), 73-97.

Christiawan, Yulius J., 2002. 'Kompetensi dan independensi akuntan publik: refleksi hasil penelitian empiris [Competence and independence of public accountants: A reflection of empirical research results]'. Jurnal Akuntansi dan Keuangan,4 (2), 6188.

Craswell, A. T., J. R. Francis, and S. L. Taylor, 1995. 'Auditor brand name reputations and Industry Specializations'. Journal of Accounting and Economics, (14), 3-49.

DeAngelo, Linda Elisabeth, 1981a. 'Auditor independence, lowballing and disclosure regulation'. Journal of Accounting and Economic, 113-127.

,1981b. 'Auditor size and audit quality'. Journal of Accounting and Economics, 183199.

Deis, Donald 1. and Gari A. Giroux, 1992. 'Determinants of audit quality in the public sector'. The Accounting Review,67 (Juli), 462-479.

Fanny, Margaretta, and Sylvia Saputra, 2005. 'Opini audit going concern: kajian berdasarkan model prediksi kebangkrutan, pertumbuhan perusahaan, dan reputasi kantor akuntan publik(studi pada emiten Bursa Efek Jakarta) [Going concern audit opinion: A study based on the bankruptcy prediction model, the company's growth and reputation of public accounting firms (studies on the listed companies in Jakarta Stock Exchange]'. Proceeding, Simposium Nasional Akuntansi ke-VIII, Solo, Indonesia.

Francis, Jere R., and Michael D. Yu, 2009. 'Big 4 office size and audit quality'. The Accounting Review,84 (5), 1521-1552.

-------, and Earl R. Wilson, 1988. 'Auditor changes: A joint test of theories relating to agency costs and auditor differentiation'. The Accounting Review, 63, 663-682. 
Geiger, Marshall A., and K. Raghunandan, 2002. 'Auditor tenure and audit reporting failures'. Auditing: AJournal of Practice \& Theory, 21 (1), 67-78.

Ghosh, Aloke, and Doocheol Moon, 2005. 'Auditor tenure and perceptions of audit quality'. TheAccounting Review, 80 (2), 585-612.

Hartadi, Bambang, 2009. 'Pengaruh fee audit, rotasi KAP, dan reputasi auditor terhadap kualitas audit di Bursa Efek Indonesia [Effect of the audit fee, audit firm rotation, and auditor reputation to audit quality in the Indonesian Stock Exchange]'. Ekuitas: Jurnal Ekonomi dan Keuangan,16 (1), 84103.

Hudaib, M. and T.E.Cooke, 2005. 'The impact of managing director changes and financial distress on audit qualification and auditor switching'. Journal of Business Finance \& Accounting, 32, 1703-1739.

Institut Akuntan Publik Indonesia, 2011. Standar Profesional Akuntan Publik [Public Accountants Professional Standards]. Salemba Empat, Jakarta.

Jackson, Andrew B., Michael Moldrich, and Peter Roebuck, 2008. 'Mandatory audit firm rotation and audit quality'. Managerial Auditing Journal,23 (5), 420-437.

Junaidi and Jogiyanto Hartono, 2010. 'Nonfinancial Factors in the Going Concern Opinion'. Journal of Indonesian Economy \& Business, 25 (3), 369-380

-------, Setiyono Miharjo, and Bambang Hartadi, 2012. 'Does auditor tenure reduce audit quality?'.Gadjah Mada International Journal of Business, 14 (3), 303-315.

--------, 2014. 'Pengaruh Tenur dan Rotasi KAP pada Independensi [The effect of tenure and audit firm rotation on independence]'.Unpublished Dissertation, Post-Graduate Programme. Yogyakarta: Universitas Gadjah Mada.

--------, Harun Pamungkas Apriyanto, Nurdiono, Eko Suwardi, 2014. 'The effect audit firm tenure in artificial rotation on audit quality'. Journal of Economics, Business, \& Accountancy (Ventura), 17 (3), 417-428.

Khomsiyah and Nur Indriantoro, 1998. 'Pengaruh orientasi etika terhadap komitmen dan sensitivitas etika auditor pemerintahan di DKI Jakarta [Effect of ethical orientation towards commitment and ethical sensitivity of government auditors in DKI Jakarta]'. Jurnal Riset Akuntansi Indonesia, 1 (1), 13-28.

Law, P., 2008. 'An Empirical Comparison of Non-Big 4 and Big 4 Auditors' Perceptions of Auditor Independence'. Managerial Auditing Journal, 23 (9), 917-934.

Lim, Chee Yeow, Hun-Tong Tan, and Qiang Cheng, 2010. 'Dosen auditor tenure improve audit quality? Moderating effects of industry specialization and fee dependence'. School of Accountancy Research Paper Series, 2 (1), 1-43.

Mai, Dao, Suchismita Mishra, and K. Raghunandan, 2008. 'Auditor tenure and shareholder ratification of the auditor'. Accounting Horizons, 22 (3), 297-234.

Maletta, M. And A. Wright, 1996. 'Audit evidence planning: An investigation of industry error characteristics. Auditing: Journal of Practice \& Theory, (15) 1, 71-86.

Mansi, S., Maxwell, W. and Miller, D., 2004. 'Does auditor quality and tenure matter to investor?' Journal of Accounting Research, 23 (2), 17-30.

Maria, Agnes and Djohan Pinnarwan, 2003. 'Independensi akuntan publik: sebuah rekapitulasi [The independence of public accountants: A recapitulation]'. Media Riset Akuntansi, Auditing dan Informasi, 3 (2), 194-215.

Mautz, R. K., and Hussein. A. Sharaf, 1961. The philosophy of auditing. American Accounting Association Monograph, Sarasota, Florida: American Accounting Assosiation.

Menteri Keuangan. 2002. Keputusan Menteri Keuangan Nomor:423/KMK.06/2002, Tentang Jasa Akuntan Publik.

.2008. Peraturan Menteri Keuangan Nomor: 17/PMK.01/2008, Tentang Jasa Akuntan Publik.

Myers, J., Myers, and T. Omer, 2003. 'Exploring the term of auditor-client relationship and the quality of earnings: A case for mandatory auditor rotation?' The Accounting Review, 78 (3),779-798.

Nasser, A.T.A., E.A. Wahid, S.N.F.S.M. Nazri, and M. Hudaib, 2006. 'Auditor-client 
relationship: The case of audit tenure and auditor switching in Malaysia'. Managerial Auditing Jurnal, 21 (7),724-737.

Nurchasanah, Rizmah and Wiwin Rahmawati, 2003. 'Analisis faktor-faktor penentu kualitas audit [Analysis of the determinants of audit quality]'. Jurnal Akuntansi dan Manajemen,(Agustus), 47-66.

Prastiwi, Andri and Frenawidayuarti Wilsya, 2009. 'Faktor-faktor yang mempengaruhi pergantian auditor: studi empiris perusahaan publik di Indonesia [The factors that affect the auditor turnover: An empirical study of public companies in Indonesia]'.Jurnal Dinamika Akuntansi,1 (1), 62-75.

Ramadhany, Alexander, 2004. 'Analisis faktorfaktor yang mempengaruhi penerimaan opini going concern pada perusahaan manufaktur yang mengalami financial distress di Bursa Efek Jakarta [Analysis of factors that affect the acceptance of a going concern opinion in the manufacturing companies experiencing financial distress in the Jakarta Stock Exchange]'. Jurnal Maksi, 4, 146-160.

Santosa, Arga Fajar, and Linda Kusumaning Wedari, 2007. 'Analisis faktor-faktor yang mempengaruhi kecenderungan penerimaan opini audit going concern [The factors analysis that affecting the tendency of going concern audit opinion]'. Jurnal Akuntansi dan Auditing, 11 (2), 141-158.

Schwartz, K.B and K. Menon, 1985. 'Auditor switches by failing firms'. The Accounting Review, 60 (2), 248-261.

Setyorini, Theresia Niken

and Aloysia Yanti Ardiati, 2006. 'Pengaruh potensi kebangkrutan perusahaan publik terhadap pergantian auditor [The influence of the potential bankruptcy of public companies towards the turn of the auditor]'. Kinerja,16 (2), 31- 40.

Sinason, David H., Jefferson P. Jones, and Sandra Waller Shelton, 2001. 'An investigation of auditor and client tenure'. American Journal of Business, 16 (2), 31-40.

Shu, S.Z., 2000. 'Auditor resignations: Clientele effects and legal liability'. Journal of Accounting and Economics, 29 (2), 173205.

Suparlan and Wuryan Andayani, 2010. 'Analisis empiris pergantian kantor akuntan publik setelah ada kewajiban rotasi audit [Empirical analysis of the turn of the audit firm after no obligation audit rotation]'. Proceeding, Simposium Nasional Akuntansi XIII, Purwokerto, Indonesia.

Notice: The Journal of Indonesian Economy and Business including the Editors decline all errors and flaws found in this article. Authors are fully responsible for them. 